\title{
Review of Energy Enhancement Protocol Wireless Sensor Networks
}

\author{
Vandna Arya \\ M. Tech Scholar \\ Department of Computer \\ Engineering and Technology, \\ Guru Nanak Dev University, \\ Amritsar, Punjab, India
}

\begin{abstract}
Wireless sensor network (WSNs) comprises of base station and number of nodes. Sometimes remote sensors are used which are generally known as remote sensor actuator systems. WSN is a large network of sensor nodes and these nodes are directly interacting with the environment by sensing the physical and ecological parameters like temperature, weight and so on. The limited energy of the sensor nodes is the major bottle neck of wireless sensor network. By conserving the on board energy, the life span of wireless sensor network can be well extensive. Data communication being the leading energy devastating movement of wireless sensor network, data decrease can provide better in conserving the nodal energy. The basic aim of this paper is to study and evaluate the performance of various techniques that are used for the communication in WSNs. The various algorithms that are used to enhance the energy of sensor nodes in wireless sensor network are portrait
\end{abstract}

\section{Keywords}

Wireless sensor network, Heterogeneous WSNs, Homogeneous WSNs, Firefly Algorithm, Clustering, Simulated annealing, Energy consumption.

\section{INTRODUCTION}

A Wireless sensor network (WSNs) consist of base station and quantity of nodes. Sometimes remote control sensor is deployed which are generally known as remote control sensor actuator systems. WSNs are spatially distributed autonomously device using sensors to monitor physical and ecological conditions like temperature, weight and so on .Remote sensors are utilized as part of military, well being, natural, car and other business applications. Sensor nodes are frequently operated by short ability battery and are unattained. WSNs nodes are regularly stationary. Remote Sensor Networks basically consists of sensors. The critical attributes of WSNs Receptors are:

- Low control

- $\quad$ Limited memory

- $\quad$ Energy manipulations because of little size.

- Wireless systems can be conveying in excessive natural conditions and might be prostrate to attacker assaults.

- Although conveyed in a specially appointed way they need to act naturally established and self-mending and can confront perpetual re-star collection.

- No crude information is transmitted, to build the life of system.
Four basic component associated with sensor nodes.

- $\quad$ Sensing device

- Processing device

- Power unit

- Transceiever

Sensing unit is employed in order to accumulate the information in analog format. Analog to digital convertors are employed to convert data fetched from analog to digital form. Microcontrollers are part of processing unit.The main task of transceiver is to tie together the sensor nodes with the network. Power device contains the battery needed to operate all the other module of the network[15]

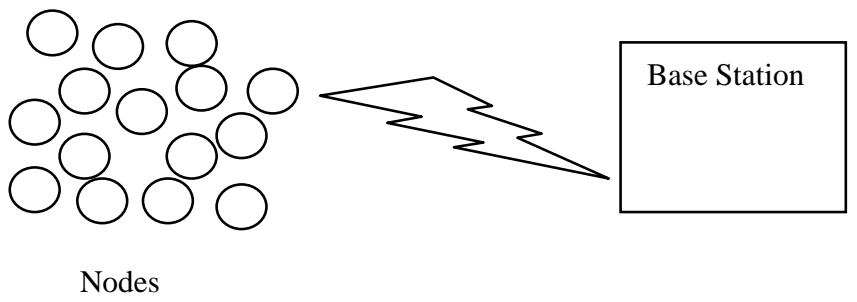

Fig no.1 Wireless Sensor Networks

The Wireless Sensor Networks are broadly divided in two categories named as:

1.1 Homogeneous Wireless Sensor Network All nodes are indistinguishable in terms of battery power \&hardware difficulty.Homogeneous system have unadulterated static bunching. Sensors networks in which hub has same equipment, multifaceted nature \& battery vitality in homogeneous sensor network.

In Homogeneous network of system utilized single system topology. In any case, the most imperative drawback of homogeneous sensor network and additionally part turn is that all system nodes will have the capability to go about as bunch heads, and therefore they must have required the ability to identify with equipment requirements.

\subsection{Hetrogeneous Wireless Sensor Network}

Heterogeneous remote sensor arrangements comprise of primarily two more hubs having diverse measure of vitality. In this sort of sensor system nodes with high measure of vitality went about as group head known as propelled nodes and nodes with less significant amount of energy called typical nodes. In Heterogeneous remote sensor systems weight based information transmission is utilized, hub having 
high measure of vitality can utilized as they brought together point and total information got information and exchange to base station. Heterogeneous system are utilized with the idea of numerous trusting keeping in mind the end goal to achieve the cluster head, the hub which are nearer to group head having more vitality weight on account of handing-off. In Heterogeneous WSN distinctive topologies are utilized \&it makes the system an extremely complex system. A Heterogeneous sensor accomplishes lowered equipment cost. Heterogeneous systems are utilizing the idea of numerous hops keeping in mind the end goal to achieve the group head, the nodes which are nearer to cluster head having the more vitality weight in view of transferring.

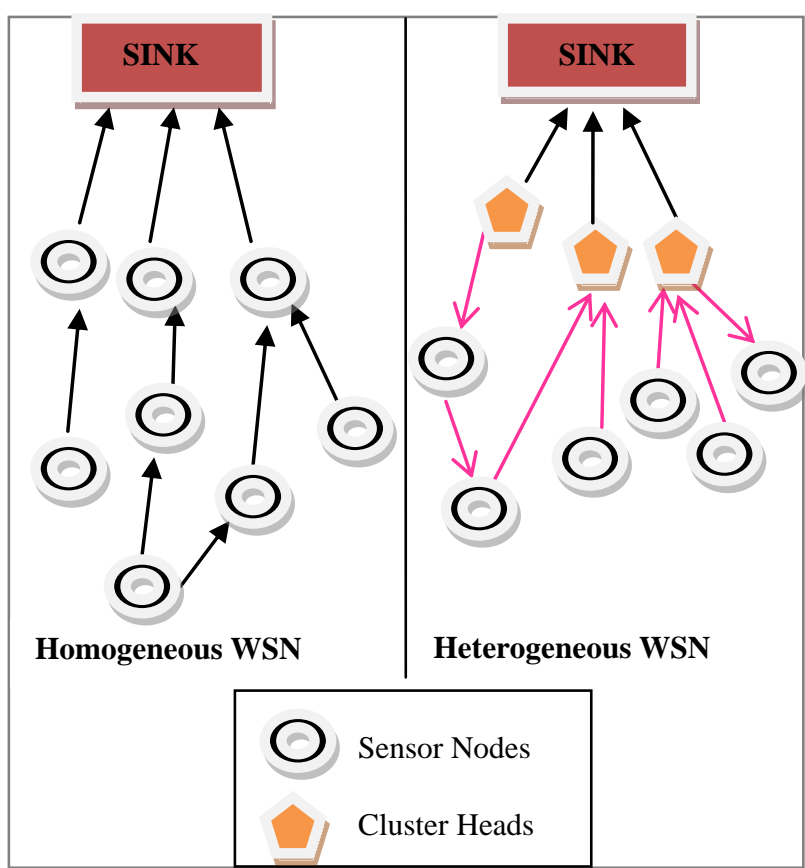

Fig no.2 Homogeneous vs. Heterogeneous WSNs

\section{CLUSTERING}

Clustering is strategy which is utilized as a part of WSNs to lessen the reduced utilization likewise decrease the no. of transmission to base station. Sensor nodes are partitioned into little gathering known as groups. Group head will gather the detected information from all nodes in that bunch. With the goal that hub will exchange their date to base station specifically. They just sense the information to $\mathrm{CH}$ of specific cluster.CH will sum up the information, wipe out repetitive information and transmit to the base station.

The nodes with most extreme fitness value will take as Cluster Head. The nodes under the correspondence will end up being an individual from Cluster Head and those nodes which has greatest vitality alongside Cluster Head is chosen as an Assistant of that group. The hub are supporting as Cluster Head that nodes will inspire opportunity to end up Cluster Head if Cluster Head dies.

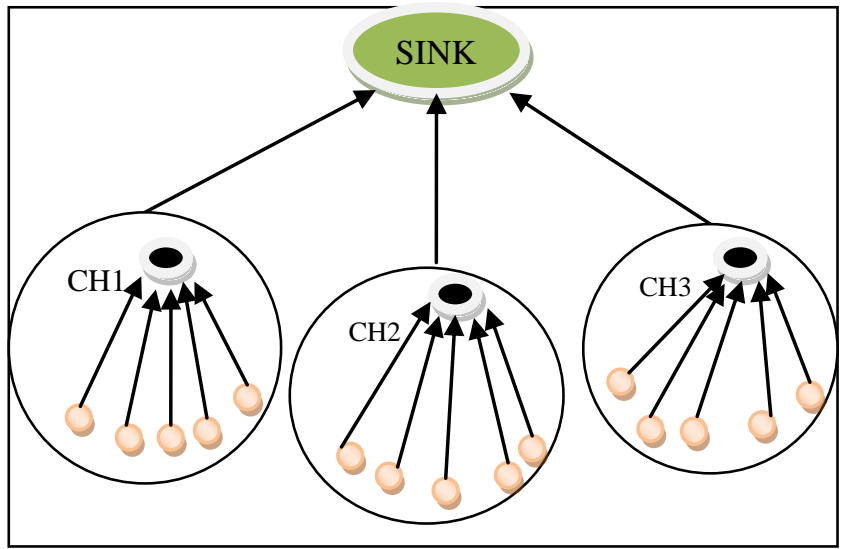

Advantages of Clustering

- Transmit entire information to the information sink.

- Diminish the quantity of hubs participating in transmission.

- Scalability for large number of hubs

- Reduces correspondence transparency for both single and multi-hop.

Topology control approach

Stack adjusting, arrange adaptability

\section{Sorts of bunching}

- Static: neighborhood topology organize

- Dynamic: altering system parameter

- $\quad$ Single hop and Multi - hop

- Homogeneous and Heterogeneous

\section{FIREFLY ALGORITHM}

The meta-heuristic calculation was proposed by Dr. Xin-She Yang at Cambridge University. The firefly Algorithm is proposed on the basis of conduct of fireflies. It finds the ideal molecule position. A firefly calculation in light of approach is suggested for vitality successful driving in Wireless sensor networks. Firefly insect generate flashes of small time through a strategy called bioluminescence. This method is evaluated after the activities of fireflies and their attraction towards different fireflies with higher power of light. Firefly Algorithm is widely used to solve reliability and redundancy problem.[12]

In firefly approach, two factors count on after light ability and appeal. Power of light is distinctly essential parameter for other firefly. This approach takes following rules:

- Firefly attracts to the other firefly on the premises of higher splendor.

- Attractiveness of fireflies on the assumption of light power straight corresponding to its higher shine.

- If distance between fireflies increments, it indicates light force is lowering.

- Objective capacity associated with brightness of firefly.

Appealing increments

The firefly algorithm is useful to improve the system lifespan \&throughput of the system with determination of Cluster 
Head on the basic of remaining vitality \&nodes in bunch scope selected to go with on the premise of separation.

In firefly annealing approach, remaining vitality ideals assume real part as esteem shared between different hubs in the systems. Number of resending of every nodes and the separation between any nodes in group is assessed. On the support of this esteem and the estimation of remaining energy, another way is set up in the system from starting to sink. The nodes which have little vitality that esteem drawn toward the high vitality node and charm is figured.[12]

In firefly annealing approach, remaining energy values assumes significant part as esteem shared between different hubs in the systems. No. of resending of every hub and the separation between any hubs in bunch is measured. On the support on this esteem and the estimation of outstanding energy, other way is found in the system from beginning to drain. [12]

The strength of the blaze light which is likewise characterized as charm is contrarily relative with removal from the sunlight source. This demonstrates the appealing increments as the declines and the other way around [12].

Appeal and Light Intensity: The associated guidelines are utilized for group arrangement.[12]

In Firefly based approach, the remaining energy value performs a major role as the values are distributed among other nodes in the network. Range of retransmissions of every nodes and the distance value between any two nodes in the cluster is determined. Depending on these values and the values of recurring energy, a new path is found in the network from source to sink. The nodes which have low energy value are fascinated towards the high energy nodes and an elegance factor is calculated. [12

In Firefly Algorithm, light concentration and attractiveness are the two important variables. Firefly is concerned toward the other firefly that has lighter spark than itself. The attractiveness is dependent on the light strength [12].

\section{SIMULATED ANNEALING}

Simulated annealing is a probabilistic method purposed in Kirkpatrick, Gelett and Vecchi (1983) and Cerny (1985) for locating the global minimum amount of a cost function that may own several local minima. It works by emulating the physical process whereby a sound is slowly cooled so that when eventually their structure is "frozen", this happen at a minimal energy arrangement.[16]

Simulated annealing is method for solving unrestrained and bounded-constrained optimization problem. The process model involves the physical procedure for heating a objects and then slowly lowering the temperatures to decrease defect, thus minimizing the system energy.[16]

At each repetition of simulated annealing criteria, a new point is randomly generated. The length of the new point from the current point, and also the extent of the search, is based on a probability allocation with a scale proportion to the temperature. The algorithm allows all new point that lower the objective, the algorithm avoid being stuck in local minima at the beginning of time and is able to explore globally for better solution [16].

The traveling salesman problem is a good example: -The sales person is looking to visit a set of town in the order that minimize the total amount of miles they travel. As the quantity of cities gets large, it comes out to be computationally too intensive to evaluate every possible itinerary. At that point, need an algorithm.[16]

Simulated annealing is a generally appropriate and easy to execute probabilistic estimation algorithm that is actually able to produce good solution. The Simulated annealing algorithm can be looked at as a local search algorithm in which there are "upward" moves that leads to an amplify in the overall cost. One hope that such upward moves will help escape local minima. The SA algorithm contains a discrete- time homogeneous Markov chain. The concurrence simulated annealing is a reassuring property, but it is far enough for SA to be an useful criteria.[16]

In an extensive Study of SA, Johnson et al. (1990, 1991, 1992) discuss the performance of SA on four problem: Travelling salesman problem(TSP), Graph partition problem(GPP), Graph coloring problem(GCP) and number partitioning problem (NPP), Johnson et al. Apply Simulated annealing to these NP-hard problems by using a cooling schedule in which the temperature reduce geometrical[16]

For Graph coloring problem in Simulated annealing, SA produces final solution that are competitive with those obtained by a modified heuristic which is considered the best one in this difficulty. on the other hand calculation times for Simulated annealing are much longer than those of the specific heuristics.[16]

In addition SA are used in double in image and various alternative version based roughly on it have been used in statistical applications. Bohachevsky, Johnson and Stein (1986) suggested a "generalized" SA produce for continuous optimization problem and applied their method to an optimal design problem.[16]

\section{RELATED WORK}

Fateh boutekkouk et al. [7] proposed a hybrid approach to expand the lifetime of heterogeneous wireless sensor network. In this paper author proposed two meta-heuristics that are: firefly and simulated annealing to expand the life span of heterogeneous wireless sensor network through fixed base station by dropping the communication utilization. The proposed approach combines the clustering and the chain approaches. This optimization algorithm tries to find the optimal clustering over the network nodes using the firefly inside each cluster it try to find the best chain using simulated annealing.

M.S.MANSHAHIA et al. [11] purposed firefly based energy well-organized routing in wireless sensor network. The firefly algorithm rules is implement in this paper that relies on the attractiveness issues on the firefly for energy efficient routing in WSNs. The firefly algorithm result displays the enhancement in the network lifetime and throughput of the network.

N.Javaid et al. [2] purposed a novel clustering based routing technique: Enhanced Energy Efficient Clustering Scheme (EDDEEC) for heterogeneous WSNs. This technique is based on dynamical changes and with more efficient the cluster head (CH) selection possibility. EDDEEC is adaptive energy responsive protocol which vigorously changes the possibility of nodes to become a $\mathrm{CH}$ in a impartial and efficient way to allocate equal amount of energy among sensor nodes.

Nafaa Jabeur et al.[5] purposed recurrent problem of node idleness in heterogeneous wireless sensor network using bully strategy. In this paper, at the end author presented an analytical approach for the recognition and relocation of 
redundant sensor of wireless networks. In this paper a bully approach is used for evaluations of overlapping between dissimilar sensing ranges.

Salah Abdel-Mageid et al. [11] purposed novel decentralizing approach enabled to consider the heterogeneous characteristics. The performance comparison is also introduced to study how to design the parameters affections. Simulation result show that purposed solution achieved high coverage performance in few rounds with minimum energy consumption and minimum computation.

Deepak R Dandekar et al. [1] in this paper have studied the problem of deploying additional relay node placement for multi-path connectivity in heterogeneous wireless sensor network. In this paper purposed that particle swarm intelligence algorithm in placing the relay nodes optimally. In this paper, in future would like to carry out same experiment to finding the optimal amount of heterogeneous wireless sensor relay nodes to be located for multipath connectivity in heterogeneous wireless network.

Ahmed Al-Saadi et a.[ 13] in this paper, a cognitive network framework for heterogeneous wireless networks is proposed, in which the network protocol stack is integrated with a semantic system. The proposed framework is used to provide on the basis for building smart network that observed the data from different layer in the network protocol stacks allowed to adding ontology to describe the data, searching the visualized data.

Ahmed M.Khedr et al. [8] purposed a new algorithm for finding the minimum connecting coverage of queried region by discovering the outmoded sensor for heterogeneous wireless sensor network, each with based on sensing range and is not responsive of its position or path of its neighbor. In the end of this paper simulation result shows that algorithm which is used that extend the lifetime of network. In future research, it will more work to focusing on distributing and localizing solution for practical deployment.

Chirihane Gherbi et.al.[16]purposed a load balancing and self adaption clustering for lifespan prolonging in huge scale in wireless sensor networks. In this paper, a new hierarchical approach called dispersed energy efficient adaptive clustering protocol with assemblage data is designed for wireless sensor network. In this paper purposed approach to range the following objective: decrease the overall network energy utilization, stability period of network, extend the lifetime of network ,the clustering should be efficient in difficulty of massage and time, load balancing should be done well. In this paper purposed work is simulated by network simulator. The main objective of this paper is to design sleep control laws that decrease the expecting rate of cost function represent both energy utilization value and share costs for backlogging Packet.

Pratyay Kuila et .at.[18] In this paper, an Energy Efficient Load Balancing algorithm that addressed energy effectiveness as well as load balancing have been discussed. The simulation result show that efficiency of designed algorithm in term of load balancing, energy effectiveness ,implementation time, the number sensor nodes dead in the network lifetime

\section{COMPARITIVE ANALYSIS}

Table1 has shown the comparison between the surveyed papers that show which algorithms yields better results in enhancing the energy and lifespan of network. The various parameters like initial energy of networks, number of bits present for message passing, number of nodes of various techniques has been compared and shown in table 1 .

Table 2 demonstrated the various techniques that are used in WSN presently. The comparisons on the behalf of various techniques based on network category, issue, benefits used to enhance the energy of network have been elaborated. It is also categorized that which technique is perform better than the available methods to recover the energy enhancement \& life span of network in wireless sensor networks.

Table1. Comparison of Heterogeneous Vs Homogeneous Networks:

\begin{tabular}{|l|l|l|l|l|l|l|l|l|l|l|}
\hline $\begin{array}{l}\text { Sr. } \\
\text { No }\end{array}$ & $\begin{array}{l}\text { Author } \\
\text { s/ } \\
\text { Year }\end{array}$ & $\begin{array}{l}\text { Network } \\
\text { Category }\end{array}$ & Protocol & $\begin{array}{l}\text { Clustering } \\
\text { Scheme }\end{array}$ & $\begin{array}{l}\text { Parameters } \\
\text { Involved }\end{array}$ & $\begin{array}{l}\text { No. of } \\
\text { Nodes }\end{array}$ & $\begin{array}{l}\text { Area } \\
\text { Field }\end{array}$ & $\begin{array}{l}\text { Initial } \\
\text { energy } \\
\text { of } \\
\text { nodes }\end{array}$ & $\begin{array}{l}\text { Stability } \\
\text { period of } \\
\text { network }\end{array}$ & $\begin{array}{l}\text { Message } \\
\text { No. } \\
\text { bits } \\
\text { of } \\
\text { Present }\end{array}$ \\
1 & $\begin{array}{l}\text { Deepak } \\
\text { R. } \\
\text { Dandek } \\
\text { ar } \\
\text { et.al[2] } \\
\text { /2013 }\end{array}$ & $\begin{array}{l}\text { Heterogeneo } \\
\text { us }\end{array}$ & $\begin{array}{l}\text { Not } \\
\text { Mentione } \\
\text { d }\end{array}$ & $\begin{array}{l}\text { Not } \\
\text { Mentioned }\end{array}$ & $\begin{array}{l}1 . \text { Number } \\
\text { of } \\
\text { sensor } \\
\text { nodes }\end{array}$ & 60 & $1000 \mathrm{~m} * 10$ & $\begin{array}{l}\text { Not } \\
\text { mention } \\
\text { ed }\end{array}$ & Yes & $\begin{array}{l}\text { Not } \\
\text { Mention } \\
\text { ed }\end{array}$ \\
\hline
\end{tabular}




\begin{tabular}{|c|c|c|c|c|c|c|c|c|c|c|}
\hline 2 & $\begin{array}{l}\text { Fatehbo } \\
\text { utekkou } \\
\text { kel.lt[7] } \\
/ 2015\end{array}$ & $\begin{array}{l}\text { Heterogeneo } \\
\text { us }\end{array}$ & $\begin{array}{l}\text { Not } \\
\text { Mentione } \\
\text { d }\end{array}$ & $\begin{array}{l}\text { Clustering } \\
\text { approach }\end{array}$ & $\begin{array}{l}\text { 1.Number } \\
\text { of nodes } \\
\text { 2.Cluster } \\
\text { number } \\
\text { 3.Field } \\
\text { dimension } \\
\text { 4.Base } \\
\text { station } \\
\text { position } \\
\text { 5.Energy of } \\
\text { all nodes } \\
\text { 6.Initial } \\
\text { temperature }\end{array}$ & 100 & $\begin{array}{l}500 \mathrm{~m} * 500 \\
\mathrm{~m}\end{array}$ & $0.1 \mathrm{~J}$ & Yes & 2000 \\
\hline 3 & $\begin{array}{l}\text { Nafaa } \\
\text { Jabeur } \\
\text { el.al[5]/ } \\
2016\end{array}$ & $\begin{array}{l}\text { Heterogeneo } \\
\text { us }\end{array}$ & $\begin{array}{l}\text { Not } \\
\text { Mentione } \\
\text { d }\end{array}$ & $\begin{array}{l}\text { Not } \\
\text { Mentioned }\end{array}$ & $\begin{array}{l}\text { 1.Network } \\
\text { field } \\
\text { 2.Residual } \\
\text { energy } \\
\text { 3.Threshold } \\
\text { redundancy } \\
\text { 4.Maximum } \\
\text { energy }\end{array}$ & $\begin{array}{l}\text { Not } \\
\text { Mentio } \\
\text { ned }\end{array}$ & $\begin{array}{l}\text { Not } \\
\text { Mentione } \\
\text { d }\end{array}$ & $\begin{array}{l}\text { Not } \\
\text { Ment } \\
\text { ioned }\end{array}$ & Yes & $\begin{array}{l}\text { Not } \\
\text { Mention } \\
\text { ed }\end{array}$ \\
\hline 4 & $\begin{array}{l}\text { Ahmed } \\
\text { M.Khed } \\
\text { r } \\
\text { et.al[8]/ } \\
2015\end{array}$ & $\begin{array}{l}\text { Heterogeneo } \\
\text { us }\end{array}$ & $\begin{array}{l}\text { Not } \\
\text { Mentione } \\
\text { d }\end{array}$ & $\begin{array}{l}\text { Not } \\
\text { Mentioned }\end{array}$ & $\begin{array}{l}\text { 1.Network } \\
\text { field } \\
\text { 2.Coverage } \\
\text { field }\end{array}$ & $\begin{array}{l}\text { Not } \\
\text { Mentio } \\
\text { ned }\end{array}$ & $\begin{array}{l}400 \mathrm{~m} * 40 \\
0 \mathrm{~m}\end{array}$ & $\begin{array}{l}\text { Not } \\
\text { Ment } \\
\text { ioned }\end{array}$ & Yes & $\begin{array}{l}\text { Not } \\
\text { Mention } \\
\text { ed }\end{array}$ \\
\hline 5 & $\begin{array}{l}\text { N.Javai } \\
\text { d } \\
\text { et.al[1] } \\
/ 2013\end{array}$ & $\begin{array}{l}\text { Heterogeneo } \\
\text { us }\end{array}$ & $\begin{array}{l}\text { Not } \\
\text { Mentione } \\
\text { d }\end{array}$ & $\begin{array}{l}\text { EDDEEC } \\
\text { (Enhanced } \\
\text { Developed } \\
\text { Distributed } \\
\text { Energy- } \\
\text { Efficient } \\
\text { Clustering) }\end{array}$ & $\begin{array}{l}\text { 1.Number } \\
\text { of sensor } \\
\text { nodes } \\
\text { 2.Network } \\
\text { field } \\
\text { 3.Energy of } \\
\text { norm nodes } \\
\text { 4.Energy of } \\
\text { an } \\
\text { advanced } \\
\text { nodes }\end{array}$ & 100 & $\begin{array}{l}100 \mathrm{~m} * 10 \\
0 \mathrm{~m}\end{array}$ & $0.5 \mathrm{~J}$ & Yes & 4000bits \\
\hline 6 & $\begin{array}{l}\text { M.S.Ma } \\
\text { nshahia } \\
\text { et.al[12] } \\
/ 2015\end{array}$ & $\begin{array}{l}\text { Heterogeneo } \\
\text { us }\end{array}$ & $\begin{array}{l}\text { Not } \\
\text { Mentione } \\
\text { d }\end{array}$ & $\begin{array}{l}\text { Not } \\
\text { Mentioned }\end{array}$ & $\begin{array}{l}\text { 1.Number } \\
\text { of nodes } \\
\text { 2.Area of } \\
\text { field } \\
\text { 3.Message } \\
\text { size } \\
\text { 4.Simulatio } \\
n \text { time }\end{array}$ & 50 & $\begin{array}{l}1000 * 100 \\
0 \mathrm{~m}\end{array}$ & $\begin{array}{l}\text { Not } \\
\text { Ment } \\
\text { ioned }\end{array}$ & Yes & $\begin{array}{l}\text { Not } \\
\text { Mention } \\
\text { ed }\end{array}$ \\
\hline 7 & $\begin{array}{l}\text { Salah } \\
\text { Abdel } \\
\text { Mageid } \\
\text { et.al[11] } \\
/ 2011\end{array}$ & $\begin{array}{l}\text { Heterogeneo } \\
\text { us }\end{array}$ & $\begin{array}{l}\text { Not } \\
\text { Mentione } \\
\text { d }\end{array}$ & $\begin{array}{l}\text { Not } \\
\text { Mentioned }\end{array}$ & $\begin{array}{l}\text { 1.Number } \\
\text { of sensor } \\
\text { nodes } \\
\text { 2.Area field }\end{array}$ & $\begin{array}{l}115,15 \\
0,180 \\
\text { and } \\
100,12 \\
0,140\end{array}$ & $\begin{array}{l}300 * 300 \\
\mathrm{~m}\end{array}$ & $\begin{array}{l}\text { Not } \\
\text { Ment } \\
\text { ioned }\end{array}$ & Yes & $\begin{array}{l}\text { Not } \\
\text { Mention } \\
\text { ed }\end{array}$ \\
\hline
\end{tabular}




\begin{tabular}{|c|c|c|c|c|c|c|c|c|c|c|}
\hline 8 & $\begin{array}{l}\text { Soichir } \\
\text { o } \\
\text { Yaman } \\
\text { ka } \\
\text { et.al[9]/ } \\
2016\end{array}$ & $\begin{array}{l}\text { Heterogeneo } \\
\text { us }\end{array}$ & $\begin{array}{l}\text { Not } \\
\text { Mentione } \\
\text { d }\end{array}$ & $\begin{array}{l}\text { Not } \\
\text { Mentioned }\end{array}$ & $\begin{array}{l}\text { 1.Number } \\
\text { of sensor } \\
\text { nodes } \\
\text { 2.Simulatio } \\
\text { n time } \\
\text { 3.Coverage } \\
\text { time }\end{array}$ & $\begin{array}{l}1000,3 \\
000,45 \\
00,600 \\
0,9000\end{array}$ & $\begin{array}{l}\text { Not } \\
\text { Mentione } \\
\text { d }\end{array}$ & $\begin{array}{l}\text { Not } \\
\text { menti } \\
\text { oned }\end{array}$ & Yes & $\begin{array}{l}\text { Not } \\
\text { Mention } \\
\text { ed }\end{array}$ \\
\hline 9 & $\begin{array}{l}\text { Salim } \\
\text { EL } \\
\text { Khediri } \\
\text { et.al[13] } \\
/ 2015\end{array}$ & $\begin{array}{l}\text { Heterogeneo } \\
\text { us }\end{array}$ & $\begin{array}{l}\text { O- } \\
\text { LEACH }\end{array}$ & $\begin{array}{l}\text { Not } \\
\text { Mentioned }\end{array}$ & $\begin{array}{l}\text { 1.Simulatio } \\
\text { n Area } \\
\text { 2.Initial } \\
\text { energy } \\
\text { 3.Base } \\
\text { Station } \\
\text { 4.Number } \\
\text { of nodes } \\
\text { 5.Transmitt } \\
\text { er/Receiver } \\
\text { electronics }\end{array}$ & $\begin{array}{l}100 \\
\text { and } \\
300\end{array}$ & $\begin{array}{l}100 * 100 \\
\mathrm{~m}\end{array}$ & $0.5 \mathrm{~J}$ & Yes & 2000bits \\
\hline 10 & $\begin{array}{l}\text { Chiriha } \\
\text { ne } \\
\text { Gherbi } \\
\text { et.al[17] } \\
/ 2015\end{array}$ & $\begin{array}{l}\text { Homogeneo } \\
\text { us }\end{array}$ & DEACP & $\begin{array}{l}\text { Not } \\
\text { mentioned }\end{array}$ & $\begin{array}{l}\text { 1.Area Field } \\
\text { 2.Data } \\
\text { packet size } \\
\text { 3. Control } \\
\text { packet size } \\
\text { 4.Initial } \\
\text { Energy } \\
\text { 5.Base } \\
\text { Station } \\
\text { 6. Distance }\end{array}$ & 100 & $\begin{array}{l}1000 * 100 \\
0 \mathrm{~m}\end{array}$ & $2 \mathrm{~J}$ & Yes & 4000bits \\
\hline 11 & $\begin{array}{l}\text { Pratyay } \\
\text { kuila } \\
\text { et.al[18] } \\
/ 2012\end{array}$ & $\begin{array}{l}\text { Homogeneo } \\
\text { us }\end{array}$ & $\begin{array}{l}\text { Not } \\
\text { Mentione } \\
\text { d }\end{array}$ & $\begin{array}{l}\text { EELBC } \\
\text { (Energy } \\
\text { Efficient } \\
\text { Load } \\
\text { balanced } \\
\text { Clustering) }\end{array}$ & $\begin{array}{l}\text { 1.Number } \\
\text { of sensor } \\
\text { nodes } \\
\text { 2.Electronic } \\
\text { energy } \\
\text { 3.Amplifier } \\
\text { energy } \\
\text { 4. Massage } \\
\text { size } \\
\text { 5.Threshold } \\
\text { distance }\end{array}$ & $\begin{array}{l}100 \text { to } \\
500\end{array}$ & $\begin{array}{l}1000 * 100 \\
0 \mathrm{~m}\end{array}$ & $2 \mathrm{~J}$ & Yes & $\begin{array}{l}\text { Not } \\
\text { Mention } \\
\text { ed }\end{array}$ \\
\hline 12 & $\begin{array}{l}\text { Santar } \\
\text { Pal } \\
\text { Singh } \\
\text { et.al[19] } \\
/ 2015\end{array}$ & $\begin{array}{l}\text { Homogeneo } \\
\text { us }\end{array}$ & $\begin{array}{l}\text { Cluster } \\
\text { based } \\
\text { routing } \\
\text { protocol( } \\
\text { LEACH, } \\
\text { HEED, } \\
\text { etc) }\end{array}$ & $\begin{array}{l}\text { Not } \\
\text { Mentioned }\end{array}$ & $\begin{array}{l}\text { Not } \\
\text { Mentioned }\end{array}$ & $\begin{array}{l}\text { Not } \\
\text { Mentio } \\
\text { ned }\end{array}$ & $\begin{array}{l}\text { Not } \\
\text { Mentione } \\
\text { d }\end{array}$ & $\begin{array}{l}\text { Not } \\
\text { menti } \\
\text { oned }\end{array}$ & Yes & $\begin{array}{l}\text { Not } \\
\text { Mention } \\
\text { ed }\end{array}$ \\
\hline 13 & $\begin{array}{l}\text { B.Manz } \\
\text { oor } \\
\text { et.al[20] } \\
/ 2013\end{array}$ & $\begin{array}{l}\text { Homogeneo } \\
\text { us }\end{array}$ & $\begin{array}{l}\text { Q- } \\
\text { LEACH }\end{array}$ & $\begin{array}{l}\text { Not } \\
\text { Mentioned }\end{array}$ & $\begin{array}{l}\text { 1.Number } \\
\text { of nodes } \\
2 \text {. Area } \\
\text { field }\end{array}$ & 100 & $\begin{array}{l}100 \mathrm{~m} * 10 \\
0 \mathrm{~m}\end{array}$ & $0.5 \mathrm{~J}$ & Yes & $2000 \mathrm{bits}$ \\
\hline
\end{tabular}




\begin{tabular}{|c|c|c|c|c|c|c|c|c|c|c|}
\hline 14 & $\begin{array}{l}\text { Gauran } \\
\text { g Raval } \\
\text { et.al[21] } \\
/ 2015\end{array}$ & $\begin{array}{l}\text { Homogeneo } \\
\text { us }\end{array}$ & $\begin{array}{l}\text { Centralize } \\
\text { d } \\
\text { protocol( } \\
\text { LEACH- } \\
\text { centralize } \\
\text { d, } \\
\text { KMeans- } \\
\text { CP,FCM- } \\
\text { CP,HSP } \\
\text { protocol) } \\
\text { Compared } \\
\text { with } \\
\text { realistic } \\
\text { topologies }\end{array}$ & $\begin{array}{l}\text { Not } \\
\text { Mentioned }\end{array}$ & $\begin{array}{l}\text { 1.Cofficient } \\
\text { of variation } \\
2 . \text { Number } \\
\text { of nodes } \\
\text { 3.Packet } \\
\text { header size } \\
\text { 4.Message } \\
\text { size } \\
\text { 5.BSlocatio } \\
\text { n } \\
\text { 6.Node } \\
\text { distribution } \\
\text { 7.Bandwidt } \\
\text { h of channel } \\
\text { 8.Initial } \\
\text { node energy } \\
\text { 9.Simulatio } \\
\text { n time } \\
\text { 10.Energy } \\
\text { consumed } \\
\text { during data } \\
\text { aggregation }\end{array}$ & $\begin{array}{l}50,100 \\
, 150,2 \\
00\end{array}$ & $\begin{array}{l}\text { Not } \\
\text { Mentione } \\
\text { d }\end{array}$ & $2 \mathrm{~J}$ & Yes & 500bytes \\
\hline 15 & $\begin{array}{l}\text { Rohini } \\
\text { Sharma/ } \\
2015\end{array}$ & $\begin{array}{l}\text { Homogeneo } \\
\text { us }\end{array}$ & LEACH & $\begin{array}{l}\text { Not } \\
\text { mentioned }\end{array}$ & $\begin{array}{l}\text { 1.Theshold } \\
\text { value } \\
\text { 2.Area field } \\
\text { 3.Initial } \\
\text { energy per } \\
\text { nodes } \\
\text { 4.Radio } \\
\text { electronics } \\
\text { energy } \\
\text { 5.Data size } \\
\text { 6.Nodes } \\
\text { 7.Radio } \\
\text { amplifier } \\
\text { energy for } \\
\text { multipath } \\
\text { fading }\end{array}$ & 100 & $\begin{array}{l}100 \mathrm{~m} * 10 \\
0 \mathrm{~m}\end{array}$ & $0.5 \mathrm{~J}$ & Yes & 100bit \\
\hline
\end{tabular}

This section provides comparison between the networks that are used to enhance the energy based on their parameters, initial energy of network. This comparison can be used for selection of optimal technique for future research.

Table2.Various techniques described through following comparison

\begin{tabular}{|l|l|l|l|l|l|l|}
\hline $\begin{array}{l}\text { Ref } \\
\text { no. }\end{array}$ & Year & Techniques & $\begin{array}{l}\text { Network } \\
\text { Category }\end{array}$ & Issues & Benefits & Limitations \\
\hline$[2]$ & 2013 & $\begin{array}{l}\text { Clustering } \\
\text { routing } \\
\text { technique }\end{array}$ & $\begin{array}{l}\text { Heterogen } \\
\text { eous }\end{array}$ & $\begin{array}{l}\text { Energy } \\
\text { consumption } \\
\text { in WSNs }\end{array}$ & $\begin{array}{l}\text { Better } \\
\text { lifetime of } \\
\text { network and } \\
\text { stability } \\
\text { period, } \\
\text { enhancement } \\
\text { of energy }\end{array}$ & $\begin{array}{l}\text { Optimize to } \\
\text { divide the } \\
\text { sensor field } \\
\text { among } \\
\text { consistent } \\
\text { number of } \\
\text { clusters. }\end{array}$ \\
\hline
\end{tabular}




\begin{tabular}{|c|c|c|c|c|c|c|}
\hline [7] & 2015 & $\begin{array}{l}\text { Meta- } \\
\text { heuristic } \\
\text { used: firefly } \\
\text { and } \\
\text { simulated } \\
\text { annealing }\end{array}$ & $\begin{array}{l}\text { Heterogen } \\
\text { eous }\end{array}$ & $\begin{array}{l}\text { To reduce } \\
\text { the energy } \\
\text { utilization } \\
\text { and improve } \\
\text { the life span } \\
\text { of network } \\
\text { and find best } \\
\text { cluster head } \\
\text {,best optimal } \\
\text { path in the } \\
\text { network }\end{array}$ & $\begin{array}{l}\text { Extend the } \\
\text { lifetime of } \\
\text { network } \\
\text { using firefly } \\
\text { and } \\
\text { simulated } \\
\text { algorithm } \\
\text { and } \\
\text { enhancement } \\
\text { of energy }\end{array}$ & $\begin{array}{l}\text { Used } \\
\text { proactive } \\
\text { protocol }\end{array}$ \\
\hline [5] & 2016 & $\begin{array}{l}\text { Bully } \\
\text { approach }\end{array}$ & $\begin{array}{l}\text { Heterogen } \\
\text { eous }\end{array}$ & $\begin{array}{l}\text { Recurrent } \\
\text { difficulty of } \\
\text { node } \\
\text { idleness in } \\
\text { Heterogeneo } \\
\text { us WSNs }\end{array}$ & $\begin{array}{l}\text { Improving } \\
\text { relocating of } \\
\text { redundancy } \\
\text { of sensor }\end{array}$ & $\begin{array}{l}\text { Complexity } \\
\text { increase } \\
\text { while solve } \\
\text { the problem } \\
\text { of } \\
\text { redundancy }\end{array}$ \\
\hline [8] & 2015 & $\begin{array}{l}\text { Localization } \\
\text { coverage } \\
\text { determinatio } \\
\mathrm{n}\end{array}$ & $\begin{array}{l}\text { Heterogen } \\
\text { eous }\end{array}$ & $\begin{array}{l}\text { Extend the } \\
\text { network } \\
\text { lifetime } \\
\text { using } \\
\text { distributed } \\
\text { algorithm }\end{array}$ & $\begin{array}{l}\text { Integration } \\
\text { of } \\
\text { Heterogeneo } \\
\text { us WSNs } \\
\text { with IP is } \\
\text { backbone of } \\
\text { 4G network }\end{array}$ & $\begin{array}{l}\text { Handoff } \\
\text { delay, packet } \\
\text { loss, packet } \\
\text { delay } \\
\text { complicated } \\
\text { to solve }\end{array}$ \\
\hline [3] & 2013 & $\begin{array}{l}\text { Mobility in } \\
\text { heterogeneo } \\
\text { us wireless } \\
\text { network }\end{array}$ & $\begin{array}{l}\text { Heterogen } \\
\text { eous }\end{array}$ & $\begin{array}{l}\text { Coverage } \\
\text { ratio \& } \\
\text { lifetime of } \\
\text { network }\end{array}$ & $\begin{array}{l}\text { Better } \\
\text { lifetime of } \\
\text { network\& } \\
\text { coverage } \\
\text { ratio }\end{array}$ & $\begin{array}{l}\text { ECRM } \\
\text { protocol is } \\
\text { highly } \\
\text { Scalable but } \\
\text { if the terrain } \\
\text { is uneven } \\
\text { extra region } \\
\text { is added } \\
\text { after the step } \\
\text { of shifting } \\
\text { the node it } \\
\text { will be } \\
\text { difficult to } \\
\text { organize the } \\
\text { network. }\end{array}$ \\
\hline [4] & 2012 & $\begin{array}{l}\text { Mobility } \\
\text { technique }\end{array}$ & $\begin{array}{l}\text { Heterogen } \\
\text { eous }\end{array}$ & $\begin{array}{l}\text { Mobility } \\
\text { management } \\
\text { with all IP in } \\
4 \mathrm{G} \text { network } \\
\text { issue such } \\
\text { context of } \\
\text { network }\end{array}$ & $\begin{array}{l}\text { Integration } \\
\text { of } \\
\text { heterogeneo } \\
\text { us network } \\
\text { with } 4 \mathrm{G} \text { is } \\
\text { backbone } \\
\text { provider }\end{array}$ & $\begin{array}{l}\text { Handoff } \\
\text { delay, packet } \\
\text { loss, packet } \\
\text { delay } \\
\text { complicated } \\
\text { to solved. }\end{array}$ \\
\hline
\end{tabular}




\begin{tabular}{|c|c|c|c|c|c|c|}
\hline [1] & 2012 & $\begin{array}{l}\text { Particle } \\
\text { swarm } \\
\text { optimization } \\
\text { technique }\end{array}$ & $\begin{array}{l}\text { Heterogen } \\
\text { eous }\end{array}$ & $\begin{array}{l}\text { Deploying } \\
\text { minimizing } \\
\text { additional } \\
\text { nodes }\end{array}$ & $\begin{array}{l}\text { Using PSO } \\
\text { algorithm } \\
\text { deploying a } \\
\text { minimum } \\
\text { additional } \\
\text { relay node to } \\
\text { process } \\
\text { multipath } \\
\text { connectivity. }\end{array}$ & $\begin{array}{l}\text { PSO } \\
\text { algorithm } \\
\text { difficult to } \\
\text { discontinuou } \\
\text { s problem in } \\
\text { variety of } \\
\text { field }\end{array}$ \\
\hline [12] & 2015 & $\begin{array}{l}\text { Firefly and } \\
\text { particle } \\
\text { swarm } \\
\text { intelligence } \\
\text { algorithm }\end{array}$ & $\begin{array}{l}\text { Heterogen } \\
\text { eous }\end{array}$ & $\begin{array}{l}\text { Network } \\
\text { lifetime and } \\
\text { throughput } \\
\text { and find the } \\
\text { best optimal } \\
\text { path in } \\
\text { network } \\
\text { using cluster } \\
\text { head at base } \\
\text { station }\end{array}$ & $\begin{array}{l}\text { Improve the } \\
\text { lifespan and } \\
\text { throughput } \\
\text { of network }\end{array}$ & $\begin{array}{l}\text { Difficult to } \\
\text { improve the } \\
\text { Stability } \\
\text { period of } \\
\text { network }\end{array}$ \\
\hline [11] & 2011 & $\begin{array}{l}\text { Adaptive } \\
\text { relocation } \\
\text { strategy }\end{array}$ & $\begin{array}{l}\text { Heterogen } \\
\text { eous }\end{array}$ & $\begin{array}{l}\text { Increase } \\
\text { lifetime and } \\
\text { reliability } \\
\text { network, } \\
\text { without } \\
\text { significantly } \\
\text { increase the } \\
\text { cost, energy } \\
\text { consumption }\end{array}$ & $\begin{array}{l}\text { Achieve } \\
\text { high } \\
\text { performance } \\
\text { in few round } \\
\text { with } \\
\text { minimum } \\
\text { energy } \\
\text { consumption } \\
\& \text { minimum } \\
\text { computation }\end{array}$ & $\begin{array}{l}\text { Different } \\
\text { operations } \\
\text { are } \\
\text { performed } \\
\text { on the basis } \\
\text { of } \\
\text { characteristi } \\
\text { cs of their } \\
\text { strategies }\end{array}$ \\
\hline [9] & 2016 & $\begin{array}{l}\text { Efficient } \\
\text { scheduling } \\
\text { method } \\
\text { based PCO } \\
\text { model. }\end{array}$ & $\begin{array}{l}\text { Heterogen } \\
\text { eous }\end{array}$ & $\begin{array}{l}\text { Collision } \\
\text { due to } \\
\text { hidden } \\
\text { nodes. }\end{array}$ & $\begin{array}{l}\text { Attain high } \\
\text { rate of data } \\
\text { gather with } \\
\text { realistic } \\
\text { coverage } \\
\text { time in } \\
\text { equally } \\
\text { Heterogeneo } \\
\text { us and } \\
\text { homogeneou } \\
\text { s network. }\end{array}$ & $\begin{array}{l}\text { PCO } \\
\text { MODEL has } \\
\text { hidden node } \\
\text { problem. }\end{array}$ \\
\hline [13] & 2015 & $\begin{array}{l}\text { Cognitive } \\
\text { network } \\
\text { framework }\end{array}$ & $\begin{array}{l}\text { Heterogen } \\
\text { eous }\end{array}$ & $\begin{array}{l}\text { Increase } \\
\text { traffic } \\
\text { demand in } \\
\text { network is } \\
\text { expected to } \\
\text { increase } \\
\text { thousand } \\
\text { fold. }\end{array}$ & $\begin{array}{l}\text { Provide } \\
\text { higher } \\
\text { network } \\
\text { capacity } \\
\text { wider } \\
\text { coverage } \\
\text { high quality } \\
\text { of service, } \\
\text { analyzing } \\
\text { search the } \\
\text { visualization } \\
\text { data }\end{array}$ & $\begin{array}{l}\text { Framework } \\
\text { is applicable } \\
\text { in network } \\
\text { layer with } \\
\text { symmetric } \\
\text { system. }\end{array}$ \\
\hline
\end{tabular}




\section{CONCLUSION AND FUTURE WORK}

In the application based WSNs location, energy and bandwidth of the sensors are appreciated resources and essential to consume capably. In this paper the energy enhancement of homogeneous and heterogamous wireless sensor networks have been surveyed and analyzed. Due to energy consumption the life span of the network would decrease; to enhance the energy and lifetime of the network. The review has shown that various algorithms which are used to improve energy enhancement of network, but still there are some issues left which decreases the network life time so to overcome these issues in near future.

\section{REFERENCES}

[1] DEEPAK R DANDEKAR and Dr. P.R.DESHMUKH, "Relay node placement for multi-path connectivity in heterogeneous wireless sensor networks", 2011 by ELSEVIER B.V.

[2] N.JAVAID, T.N.QURESHI, A.H.KHAN, A.IQBAL, E.AKHTAR and M.ISHFAQ, "EDDEEC: Enhanced developed distributed energy-efficient clustering for heterogeneous wireless sensor networks", 2013 by ELSEVIER B. V.

[3] DURGA PAVAN NUDURPATI and RAJAT KUMAR SINGH, "Enhancing coverage ratio using mobility in heterogeneous wireless sensor network", 2013 by ELSEVIER B.V.

[4] B.R.CHANDAVARKAR and G.RAM MOHAN REDDY, "Mobility management in heterogeneous wireless network", 2011 by ELSEVIER B.V.

[5] NAFAA JABEUR, AHMED NAIT SIDI MOH and MOHAMED MAHDI BARKIA, "A bully approaches for competitive redundancy in heterogeneous wireless sensor networks, 2016 by ELSEVIER B.V.

[6] MARCO VALERO, SANG SHIN JUNG, A. SELUK ULUAGAC, YINGSHU LI and REHEEM BEYAH, "DI-SEC: A distributed security framework for heterogeneous wireless sensor network, 2012 by IEEE.

[7] FATEH BOUTEKKOUK, FATIMA TAIBI and KHAWLA MEZIANI, "A hybrid approaches to extend the lifetime of heterogeneous wireless sensor networks, 2015 by ELSEVIER B.V.

[8] AHMED M. KHEDR, "Location-free minimum coverage determination in a heterogeneous wireless sensor networks, 2015 by ELSEVIER B.V.

[9] SOICHIRO YAMANKA, MASAFUMI HASHIMOTO and NAOKI WAKAMIYA,"An efficient scheduling method based on pulse-coupled oscillator model for heterogeneous large-scale wireless sensor networks", 2016 by ELSEVIER B.V.

[10] CHEIN-LIANG FOK, GRUIA-CATALIN ROMAN and CHENYANG LU, "Seville A flexible service provisioning middleware for heterogeneous wireless sensor networks", 2010 ELSEVIER B.V.

[11] SALAH ABDEL-MAGEID and MOHAMED ZAKI, "An adaptive relocation strategy for heterogeneous sensor Networks", 2011 by ELSEVIER B.V.

[12] M.S.MANSHAHIA, "A firefly based energy efficient routing in wireless sensor network", 2015 by IEEE.

[13] SALIM EL KHEDIRI, NAJEH NASRI, ANNE WEI and ABDENNACEUR, "An approach for clustering in wireless sensor networks based on LEACH", 2014 by ELSEVIER B.V.

[14]AHMED AL-SAADI, ROSSITZA SETCHI, YULIA HICKS, "cognitive network framework for heterogeneous wireless sensor network, 2015 by ELSEVIER B.V

[15] A.KAUR and A .Singh, "A Review on enhancement of lifetime of wireless sensor network using prediction based mobile sink path determination: a review,"pp.14120-14126, 2016

[16] Dimitris Bertsimas and John Tsistsiklis, "Simulated Annealing", Dept of ELECTRICAL AND COMPUTER SCIENCE, MASSACHUSETTS INSTITUTE OF TECHNOLOGY, CAMBRIDGE, MASSCHUSETTS 02139

[17] Chirihane Gherbi, Zibouda Aliouat, Mohammed Benmohammed, "A Load balancing and self-adaption clustering for lifetime prolonging in large scale wireless sensor network", 2015 by ELSEVIER B.V.

[18] Pratyay Kuila, Prasanta K. Jana, "Energy efficient loadbalanced clustering algorithm for wireless sensor network", 2012 by ELSEVIER B.V.

[19] Santar Pal Singh, S.C.Sharma, "A survey on cluster based routing protocol in wireless sensor networks", 2015 ELSEVIER B.V.

[20] B.Manzoor, N.Javaid, O.Rehman, M.Akbar, Q.Nadeen, A.iqbal, M. ishfaq, "Q-Leach: A new Routing Protocol for WSNs, 2013 by ELSEVIER B.V.

[21] Gaurang Raval, Madhuri Bhavsar, Nitin Patel, "Analyzing the performance of centralized clustering techniques for realistic wireless sensor network topologies", 2015 ELSEVIER B. V. 